\title{
GENEZA CHRZEŚCIJAŃSKIEJ POSŁUGI HOSPICYJNEJ
}

Troska o cierpiącego człowieka to najszczególniejszy przejaw miłości bliźniego. Na pytanie, kim jest mój bliźni, Jezus nie odpowiedział wprost, lecz odwołał się do przypowieści o miłosiernym Samarytaninie, który zaopiekował się człowiekiem poranionym przez zbójców (por. Łk 10, 25-37). Ów Samarytanin, gdy zauważył cierpiącego wskutek ran człowieka, to „opatrzył mu rany, zalewając je oliwą i winem" (Łk 10,34). Leżącym półumarłym człowiekiem nie zainteresowali się przedstawiciele władz świątyni, a więc kapłan i lewita, a jeśli tak było, to ich postawa prawdopodobnie wynikała z tego, że ów leżący przy drodze człowiek nie przynależał do ich wspólnoty religijnej. Nie czuli się zatem za niego odpowiedzialni, a ponadto nie chcieli, poprzez pomoc poranionemu obcemu, stać się rytualnie nieczystymi. Przypowieść o miłosiernym Samarytaninie była więc prowokacją ze strony Jezusa skierowaną przeciwko ekskluzywistycznej religijności narodu wybranego, który był przekonany, że jedynie on godzien jest doświadczać troski Boga. Wszyscy zaś nie przynależący do judaistycznej wspólnoty religijnej nie mają i nie powinni mieć udziału w miłosierdziu Boga. Jezus opowiadając przypowieść o miło-

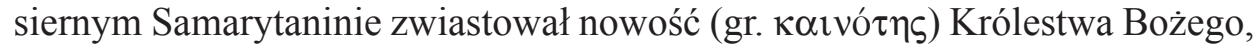
w ramach którego kapłan i lewita nie czyniący miłosierdzia wobec obcych zostaną wykluczeni, natomiast wygnańcy i banici zostaną przygarnięci przez miłosiernego Boga. Właśnie z tego powodu obraz miłosiernego Samarytanina musiał być szokujący dla społeczności żydowskiej. W Ewangelii według św. Łukasza przypowieść ta miała na celu uwrażliwienie umysłów Żydów na Boga otwartego na los każdego człowieka ${ }^{1}$. Miłość bliźniego ma swoje źródło w umiłowaniu Boga. Tajemnica miłości Boga i bliźniego łączy Stare Przymierze z głoszeniem Dobrej Nowiny o Królestwie Bożym. Na pytanie uczonego w Piśmie: „Które jest pierwsze ze wszystkich przykazań?” (Mk 12, 28), Jezusa udzielił odpowiedzi, która ma być światłem rozświetlającym cel i sens chrześcijańskiego życia:

* Dr hab. Krzysztof Leśniewski, prof. KUL - kierownik Katedry Teologii Prawosławnej w Instytucie Ekumenicznym na Wydziale Teologii Katolickiego Uniwersytetu Lubelskiego Jana Pawła II; e-mail: lesni@kul.lublin.pl.

${ }^{1}$ Por. K.A. Reich, Figuring Jesus. The Power of Rhetorical Figures of Speech in the Gospel of Luke, Leiden - Boston (Mass.) 2011, 105; S.H. Ringe, Luke, Luisville (Ky) 1995, 158; B. Malina - R.L. Rohrbaugh, Social Commentary on the Synoptic Gospels, Minneapolis (Minn.) 1992, 347. 
„Będziesz miłował Pan, Boga swego, całym swoim sercem, całą swoją dusza, całym swoim umysłem i całą swoją mocą. [...] Będziesz miłował swego bliźniego jak siebie samego" (Mk 12, 30-31).

Nie jest możliwe zrozumienie istoty chrześcijańskiej posługi hospicyjnej ${ }^{2}$ bez odniesienia się do Jezusa Chrystusa, który stał się człowiekiem i umarł na krzyżu dla zbawienia ludzi. To była największa cena miłości Boga do człowieka. Pragnienie naśladowania Jezusa, wynikające z doświadczenia Boga jako osobowej Miłości, już od samego początku istnienia chrześcijaństwa było czymś wyjątkowym zarówno dla świata semickiego, jak i dla ówczesnej cywilizacji grecko-rzymskiej. Zaangażowanie chrześcijan w pomoc cierpiących, niezależnie od tego, czy przynależeli do wspólnoty wierzących czy też byli niewierzącymi, wynikało z ich codziennego doświadczenia, że „Bóg jest miłością” (1J 4, 8). Sw. Jan Apostoł w Pierwszym Liście zachęcał: „Umiłowani, miłujmy się wzajemnie, ponieważ miłość jest z Boga, a każdy, kto miłuje, narodził się z Boga i zna Boga. [...] W tym objawia się miłość Boga ku nam, że zesłał Syna swego Jednorodzonego na świat, abyśmy życie mieli dzięki Niemu. [...] Umiłowani, jeśli Bóg tak nas umiłował, to i my winniśmy się wzajemnie miłować" (1J 4, 7. 9. 11). Zachęta do miłowania braci (por. J 4, 21) nie ograniczała się jedynie do wspólnoty wierzących w Zmartwychwstałego Pana, lecz zobowiązywała do otwarcia na potrzeby wszystkich, którzy potrzebowali pomocy ${ }^{3}$. Jezus Chrystus ,umarł za wszystkich” $(2$ Kor 5,14$)$ i pragnie „aby wszyscy byli zbawieni i doszli do poznania prawdy” $(2 \mathrm{Tm} 2,4)^{4}$. Od początku istnienia Kościoła świadczenie miłości cierpiącym było praktycznym wyrazem świadectwa wiary w Boga, który jest Miłością. Począwszy od troski o potrzebujących w czasach wspólnoty apostolskiej i posługi diakonów (por. Dz 6, 1-6), w ramach chrześcijaństwa podejmowane były różnego rodzaju działania, których celem była również opieka nad cierpiącymi i chorymi. W ciągu pierwszych kilku wieków wspólnoty chrześcijańskie zorganizowały różnego rodzaju pomoc dla chorych i będących w potrzebie, która była zjawiskiem wyjątkowym w całym ówczesnym świecie pogańskim ${ }^{5}$. Już w III w. w wielkich miastach Cesarstwa Rzymskiego, chrześcijańska działalność dobroczynna oraz opiekuńcza była dobrze zorganizowana ${ }^{6}$. W Kościołach

${ }^{2} \mathrm{Na}$ temat nazwy, genezy, rozwoju, struktury i organizacji hospicjum por. S. Longosz, Ksenodochium - hospicjum wczesnochrześcijańskie, VoxP 16 (1996) t. 30-31, 275-336.

${ }^{3}$ Por. D.W. Riddle, Early Christian Hospitality: A Factor in the Gospel Transmission, JBL 57 (1938) nr 2, 141-154.

${ }^{4}$ Por. H. Ordon, Pawłowa argumentacja na rzecz niesienia pomocy potrzebujacym, VoxP 16 (1996) t. 30-31, 75-83.

${ }^{5}$ Por. G.B. Ferngren, Medicine and Health Care in Early Christianity, Baltimore (Md) 2009, 114; D. Porter, Health, Civilization and the State. A History of Public Health from Ancient to Modern Times, London - New York (NY) 1999, 20-23.

${ }^{6} \mathrm{~W}$ Cesarstwie rzymskim do powstania szpitali przyczyniła się dobroczyno-opiekuńcza działalność chrześcijan oraz potrzeba interwencji lekarskich dla żołnierzy walczących w legionach. Por. G. Rosen, A History of Public Health, Baltimore - London 1958, 24. 
lokalnych zbierano znaczne sumy pieniędzy, które przeznaczano na szeroko rozumianą działalność charytatywną, a zwłaszcza na opiekę nad ludźmi chorymi. Chrześcijańscy diakoni, wspierani przez zastępy subdiakonów, akolitów, egzorcystów, lektorów i odźwiernych skupiali się na potrzebach cierpiących, a zwłaszcza na osobach ciężko i nieuleczalnie chorych. Trzeba podkreślić, że w ramach troski o chorych i cierpiących nie było dokonywane rozróżnienie pomiędzy braćmi i siostrami w wierze a poganami. Tak, jak Chrystus przyszedł do wszystkich, tak też chrześcijanie dostrzegali Jego Oblicze we wszystkich cierpiących i chorych oraz wszystkim świadczyli dobro.

W IV w., po ustaniu prześladowań chrześcijan, następuje okres rozwoju życia monastycznego. Na terenach Cesarstwa Bizantyńskiego monastery cenobityczne stały się nie tylko miejscami, w których mnisi zmagali się duchowo na drodze zbawienia, ale również miejscami, w których zostały powołane do istnienia pierwsze szpitale, stanowiące całkowitą nowość w świecie starożytnym ${ }^{7}$. Jeśli poszukujemy genezy chrześcijańskiej posługi hospicyjnej, to jest bezspornym faktem, iż miejscem właściwym jej zaistnienia były właśnie monastery. Mnisi w bardzo dużym stopniu przejęli prace związane z pielęgnowaniem chorych i to zarówno tych, którzy mieli szansę na wyzdrowienie, jak i chorych terminalnie, a zwłaszcza trędowatych. Zakres opieki dobroczynnej, jaka była świadczona przez mnichów, był szeroki i dostosowany do specyficznych potrzeb tych, którzy jej potrzebowali. Oprócz specjalistycznej opieki nad terminalnie chorymi, czyli posługi hospicyjnej, w polu zainteresowania mnichów były również: sieroty, podrzutki, chorzy biedni wędrowcy oraz ludzie niedołężni i w podeszłym wieku. Chrześcijanie poprzez opiekę nad chorymi i umierającymi spowodowali rewolucyjną zmianę w społeczeństwie starożytnym, które nie miało żadnej wrażliwości na ludzi cierpiących. Chrześcijaństwo pojawiło się w świecie jako religia uzdrowienia, a zarazem jako radosna Dobra Nowina o Bogu zbawiającym człowieka. Chrześcijaństwo było religią nadziei dla chorych i dotkniętych cierpieniem, gdyż zwiastowało przywrócenie zdrowia zarówno duchowego, jak i fizycznego. Troska o wszystkich będących w pobliżu chorych stała się obowiązkiem chrześcijan. W wyniku tego radykalnie zmieniła się społeczna pozycja chorych, w tym również chorych terminalnie, w ówczesnym świecie. Chorzy, którzy uprzednio byli wyrzucani poza społeczeństwo, zajęli uprzywilejowaną pozycję, jaka nigdy wcześniej nie była dla nich możliwa do osiagnięcia ${ }^{8}$. Do czasu bowiem opieki nad chorymi jaką zapewniło chrześcijaństwo, chorzy, którzy padli ofiarą zarazy czy trądu, byli porzucani przez swych krewnych i skazywani na cierpienie bez

${ }^{7}$ Por. T.S. Miller, The Birth of the Hospital in the Byzantine Empire, Baltimore (Md) 1985, 30-49; P. Horden, The Christian Hospital in Late Antiquity: Break or Bridge?, w: GesundheitKrankheit. Kulturtransfer medizinischen Wissens von der Späntantike bis in die Frühe Neuzeit, ed. F. Steger - K.P. Jankrift, Cologne 2004, 88-92; G.B. Risse, Mending Bodies, Saving Souls: A History of Hospitals, New York 1999, 69-116.

${ }^{8}$ Por. H.E. Sigerist, Civilization and Disease, Ann Arbor (MI) 1915, 69-70. 
jakiejkolwiek opieki aż do śmierci. Chrześcijanie spieszyli by opiekować się

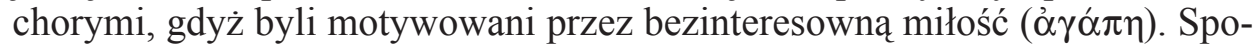
glądali z miłością na wszystkich cierpiących, gdyż dostrzegali w nich ludzi

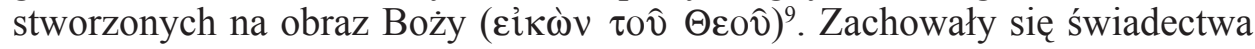
dotyczące hierarchów oraz środowisk monastycznych, które oddziaływały na zmianę sposobu traktowania chorych, którzy nie mieli środków na skorzystanie z pomocy lekarzy oraz cierpiących na choroby nieuleczalne. Początek największych zmian przypada na 2. poł. IV w., a więc czas, gdy chrześcijaństwo zaczęło zyskiwać uprzywilejowaną pozycję w basenie Morza Śródziemnego. Warto wskazać na kilka przykładów, dzięki którym stanie się bardziej oczywiste, jaki był i na czym polegał wkład chrześcijaństwa w przemiany społeczne dotyczące sposobu traktowania chorych.

Klęska głodu w 369 r. na terenie Kapadocji skłoniła św. Bazylego Wielkiego, gdy został biskupem Cezarei w roku 370, do podjęcia szeregu działań, aby zapewnić ubogim i chorym dobrze zorganizowaną pomoc o charakterze instytucjonalnym. Ich owocem było powstanie pierwszego szpitala w 372 lub $373 \mathrm{roku}^{10}$. Była to instytucja, którą zwano przytułkiem - domem dla biednych ( $\pi \tau \omega \chi 0 \tau \rho \circ \varphi \varepsilon \hat{\imath} о v)$, schroniskiem ( $\xi \varepsilon v o \delta o \chi \varepsilon \hat{\imath} o v)$ lub też domem odpoczynku

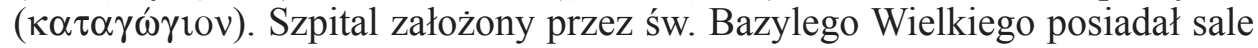
dla chorych, przytułek dla ludzi biednych i starych, schronisko dla podróżujących i bezdomnych oraz hospicjum dla trędowatych. W kompleksie budynków było również schronisko dla odwiedzających oraz zabudowania monasterskie dla mnichów, jak również kuchnie, refektarze, łaźnie, magazyny oraz budynki mieszkalne dla pracujących, którzy nie byli mnichami. Całość była tak wielka,

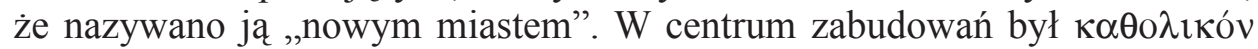
- świątynia, w której celebrowane były Eucharystie oraz odprawiane były wspólne modlitwy. W tym pierwszym szpitalu chorzy mieli zapewnioną zarówno opiekę duchową, jak i opiekę lekarską. Św. Bazyli Wielki w zbudowanym centrum, zwanym od V w. Basileias ${ }^{11}$, zatrudniał lekarzy, którzy leczyli korzystając z wiedzy medycznej, jaka dostępna była w świecie grecko-rzymskim. Prawdopodobnie ze względu na to, że w szpitalu był również oddział dla trędowatych (leprozorium) został on zbudowany poza miastem. Oprócz opieki nad trędowatymi, w szpitalu troszczono się również o biednych, przybyszów i bezdomnych, sieroty, starców i ludzi niedołężnych, jak również chorych ${ }^{12}$.

\footnotetext{
${ }^{9}$ Por. H. Flemming, Post-Hippocratic Medicine: The Problem and the Solution. How the Christian Ethic has Influenced Health Care, Taunton 2010, 30-31.

${ }^{10}$ Por. Gregorius Nazianzenus, Oratio 43, 63, PG 36, 577C - 580B; I. Karagiannopoulos,

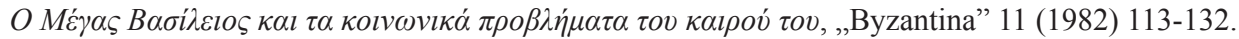

${ }^{11}$ Por. J. Naumowicz, Instytucje charytatywne św. Bazylego. „Bazyliada”, VoxP 16 (1996) t. 30-31, 125-139.

${ }^{12}$ Por. A.T. Crislip, From Monastery to Hospital: Christian Monasticism and the Transformation of Health Care in Late Antiquity, Ann Arbor (MI) 2005, 103-106.
} 
W refleksji nad genezą chrześcijańskiej posługi hospicyjnej na szczególną uwagę zasługuje opieka nad trędowatymi. Trzeba pamiętać, że w starożytności trędowaci nie mieli prawa do życia w społeczeństwie. Byli pogardzani i wyrzucani $z$ terenów zamieszkałych. $Z$ trudem udawało im się wyżebrać jakieś resztki jedzenia na rynkach czy przy świątyniach ${ }^{13}$. Jak już zostało to wspomniane, św. Bazyli Wielki jedną z części szpitala przeznaczył dla trę-

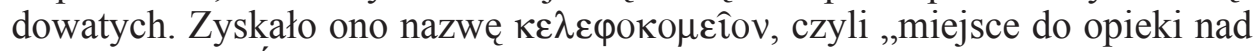
trędowatymi”. Ów dom dla trędowatych był właściwie tym, czym obecnie jest hospicjum, czyli miejscem troski o terminalnie chorych, dla których nie ma nadziei na odzyskanie zdrowia. Trędowatym nie tylko dano miejsce do mieszkania oraz żywiono ich, ale również troszczono się o ich ciała. Starożytni lekarze nie leczyli chorych, którym nie dawali szans na wyzdrowienie, gdyż w ten sposób mogli by pomniejszyć lub nawet stracić swą medyczną reputację. Zachowało się świadectwo św. Grzegorza z Nazjanzu opisujące wyjątkowość miejsca, w którym znaleźli schronienie i opiekę trędowaci:

„Już dłużej nie ma przed naszymi oczami okropnego i żałosnego widowiska ludzi, którzy są żyjącymi zwłokami. Jakże trudno patrzeć na tych, których ciała w większej części są już obumarłe. Nie oglądamy już jak są wyrzucane ze swych miast i domów oraz miejsc publicznych i fontann, jak również odłączani są od swych najbliższych. Ich ciała są tak zmienione przez trąd, że nie można ich rozpoznać z wyglądu, lecz jedynie z imion. Nie przychodzą już na nasze zebrania i spotkania. Nie są już przedmiotem nienawiści. Ich choroba skłania do współczucia i litości”"14.

Chrześcijańska troska o trędowatych zdumiewała pogan. Św. Bazyli Wielki zapewnił trędowatym dobre warunki do powolnego umierania z zachowaniem godności oraz uczył wiernych traktowania ich jak braci. Leprozorium św. Bazylego Wielkiego stanowiło przykład do naśladowania dla innych ${ }^{15}$. Ze względu na to, że założony przez niego szpital stanowił integralną część monasteru, istotna była również troska o życie duchowe pacjentów. Mieli oni zapewnioną opiekę pastoralną i możliwość wsłuchania się w modlitwy mnichów. Od trędowatych oczekiwano, aby zachowywali się w sposób zgodny z chrześcijańską moralnością. Godnym podkreślenia jest fakt, iż Biskup Cezarei Kapadockiej skłaniał możnowładców i ludzi bogatych, aby wspierali nowy program chrześcijańskiej instytucjonalnej dobroczynności ${ }^{16}$.

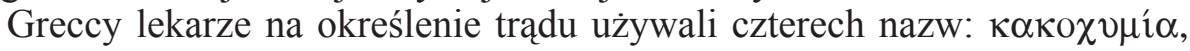

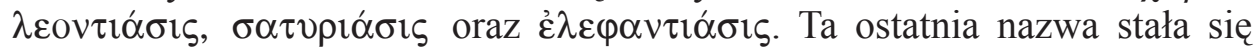
najbardziej powszechna. Trąd zatem w tradycji bizantyńskiej określany był

${ }^{13}$ Por. H. Avalos, Health Care and Rise of Christianity, Grand Rapids (MI) 1999, 67-68.

${ }^{14}$ Gregorius Nazianzenus, Oratio 43, 63, PG 36, 577C - 580B, thum. własne.

${ }_{15}$ Por. M. Foucault, The Birth of the Clinic: An Archeology of Medical Perception, transl. A.M.S. Smith, New York 1973, 102.

${ }^{16}$ Por. Ferngren, Medicine and Health Care in Early Christianity, s. 129. 
słowem „słoniowatość" ${ }^{17}$. Choroba ta znana była w świecie starożytnym. Wzmianki o niej pojawiają się w Starym Testamencie. W Ewangelii według św. Mateusza znalazł się opis uzdrowienia trędowatego przez Jezusa, zaraz jak skończył kazanie na górze. Jezus wyciagnął rękę, dotknął trędowatego i powiedział: „Bądź oczyszczony”. Człowiek ów został natychmiast uzdrowiony (por. Mt 8,1-4). Pierwsi chrześcijanie rozumieli znaczenie dobra, jakie czynił Jezus, ale potrzebowali co najmniej kilkadziesiąt lat, aby w swoim działaniu dobroczynnym ( $\left.\varphi \imath \lambda \alpha \nu \theta \rho \omega \pi^{\prime} \alpha\right)$ przekraczać granice nakreślone przez Prawo żydowskie. Na podstawie zachowanych dzieł z II w. można wnioskować, że już wtedy chrześcijanie praktykowali cały szereg działań dobroczynnych ukierunkowanych na wdowy, sieroty, biednych czy chorych.

$\mathrm{Na}$ postawie zachowanych źródeł historycznych można wnosić, iż nie wcześniej niż w IV w. nastąpiło rozprzestrzenienie się trądu w Kapadocji i Italii ${ }^{18}$. Starożytnym greckim lekarzom nie udało się znaleźć skutecznego sposobu leczenia trądu. Stąd też w pogańskim świecie hellenistycznym, tak samo jak i w środowisku żydowskim, trędowatych wyrzucano z życia społecznego, traktując ich jako ludzi niebezpiecznych, zagrażających zdrowiu i nieczystych. Zmiana sposobu ich traktowania dokonała się dopiero w chrześcijańskim Bizancjum. Tam bowiem w środowiskach kościelnych i przy wsparciu władz państwowych udało się stworzyć środowisko, w którym ofiary trądu otrzymały opiekę paliatywną. I co istotne, trędowaci nie zostali skazani na banicję społeczna, jak to okazjonalnie zdarzało się na średniowiecznym Zachodzie, lecz stali się podmiotem szczególnej troski ze strony środowisk monastycznych. Ponadto, autorytety kościelne wpłynęły na zmianę nastawienia społeczeństwa wobec chorych na trąd oraz samej choroby, która zyskała nazwę „świętej choroby”. Zmiana nazwy trądu na „świętą chorobę" miała na celu przekonanie ludzi, że Bóg nie zesłał tej choroby, aby w ten sposób ukarać za popełnione grzechy, lecz aby oczyścić ich dla nieba i uczynić ich świętymi ${ }^{19}$. Do takiej zmiany świadomości szczególnie przyczynili się wielcy święci: wspomniany już Bazyli Wielki, jak również Grzegorz z Nyssy, Grzegorz z Nazjanzu i Jan Chryzostom, którzy wygłosili wiele kazań odnoszących się do ówczesnego kryzysu zdrowia publicznego oraz sytuacji trędowatych. Św. Grzegorz z Nyssy przedstawiał trędowatych jako ofiary pozbawione możliwości funkcjonowania w społeczeństwie. W dramatyczny sposób opisywał ich cierpienie, związane z utratą poszczególnych części ciała oraz problemy z oddychaniem i brakiem czucia ${ }^{20}$. Św. Jan Chryzostom, wkrótce po wybraniu na biskupa Konstantynopola w 398 r., wybudował szpital dla trędowatych blisko stolicy

${ }^{17}$ T.S. Miller - J.W. Nesbitt, Walking Corpses. Leprosy in Byzantium and the Medieval West, Ithaca - London 2014, 8.

${ }^{18}$ Por. tamże, s. 26.

${ }^{19}$ Por. tamże, s. 27-28.

${ }^{20}$ Por. Gregorius Nyssenus, De pauperibus amandis orationes duo, ed. A. van Hecks, Leiden 1964, passim. 
Cesarstwa Bizantyńskiego. $\mathrm{Z}$ anonimowej oracji pogrzebowej ku jego czci dowiedzieć się można, iż na wybudowanie azylu dla trędowatych wpłynęło jego osobiste spotkanie z niezliczonymi ofiarami trądu, które były porzucone wzdłuż głównych dróg w prowincji Bitynia, która znajdowała się po azjatyckiej stronie Bosforu ${ }^{21}$. Według starej tradycji ok. 360 r. cesarz Konstancjusz II rozbudował maleńki szpital dla trędowatych, który wcześniej został założony przez kapłana imieniem Zotikos na północnym wybrzeżu Złotego Rogu. Kolejni imperatorzy, a zwłaszcza Justyn II (565-572) oraz Maurycy (582-602) przebudowywali to leprozorium po atakach plemion barbarzyńskich z północy. Zostało ono częściowo zburzone, gdyż nie miało murów obronnych, które chroniły pobliski Konstantynopol. Leprozorium Zotikos rozbudowano w X w. Cesarze Konstantyn VII i Jan Tzimiskes wybudowali nowe dormitoria, dzięki czemu w Zotikosie przebywało dwukrotnie więcej trędowatych niż uprzednio. Po trzęsieniu ziemi w XI w., cesarz Romanos III (1028-1034) na miejscu zawalonych budynków szpitalnych wybudował nowe. Wiadomo też, że cesarz Jan II Komnenos również przeznaczył znaczne środki finansowe na wybudowanie kolejnych dormitoriów i opiekę nad trędowatymi ${ }^{22}$.

W końcu IV w. szpital dla trędowatych został wybudowany w Antiochii, a w wiekach V i VI wybudowano też kilka szpitali w Palestynie. Podobnie w Eddesie w 411 r., gdy Rabbula został wybrany na biskupa, wybudował dla trędowatych szpital ${ }^{23}$ oraz wyznaczył diakona, by nim zarządzał, jak również zatrudnił personel pomocniczy do opieki oraz przygotowywania posiłków i opieki paliatywnej. Z funduszy kościelnych opłacane były wszelkie koszty związane z pobytem trędowatych w przeznaczonym dla nich szpitalu ${ }^{24}$.

W Cesarstwie Bizantyńskim darowizny na szpitale były zwolnione od podatków. Oprócz darowizn od ludzi bogatych istotną część funduszy na funkcjonowanie szpitali stanowiły składki pochodzące bezpośrednio od wiernych ${ }^{25}$. W kolejnych dziesięcioleciach IV w. dobroczynność chrześcijańska ukierunkowana na chorych, a zwłaszcza na chorych terminalnie, stawała się powszechną praktyką. W szpitalach chorymi opiekowali się nie tylko posiadający profesjonalną wiedzę medyczną lekarze, ale również pomocnicy ( $(\pi 0 v \rho \gamma o u ́)$, którymi byli zarówno mnisi, jak i ludzie świeccy, którzy nie mieli

${ }^{21}$ Por. T.S. Miller - J. Nesbitt, Saint John Chrysostom and the „,Holy Disease”: an excerpt from an unpublished, anonymous eulogy (BHG 871; CPG 6517), „Rivista di studi bizantini e neoellenici” 42 (2006) 33-34; G. Sidéris, Lèpre et lépreux à Constantinople. Maladie, épidémie et idéologie imperial à Byzance, w: La Paléodémographie. Mémoire d'os, memoire d'hommes. Actes des $8^{e}$ journées antropologiques de Valbonne 5 au 7 Juin 2003, ed. L. Buchet - C. Dauphin - I. Séguy, Antibes 2006, 187-207.

${ }^{22}$ Por. Miller - Nesbitt, Walking Corpses, s. 34-36.

${ }^{23}$ Por. P. Szczur, Rabula, EK XVI 1023.

${ }^{24}$ Por. A. Vööbus, History of Asceticism in the Syrian Orient. A Contribution to the History of Culture in the Near East, I: The Origin of Asceticism. Early Monasticism in Persia, Leuven 1958, 386.

${ }^{25}$ Por. J. Fijałek, Rozwój szpitalnictwa, w: Historia medycyny, red. T. Brzeziński, Warszawa 1995, 398-399. 
przeszkolenia medycznego. Szpitale stanowiące integralną część monasterów budowane były zazwyczaj tuż przy głównej świątyni ( $\kappa \alpha \theta 0 \lambda \iota \kappa o ́ v)$, aby chorzy mieli możliwość wsłuchania się we wspólne modlitwy mnichów oraz uczestnictwa, w miarę możliwości, w sprawowanych tam nabożeństwach i Boskiej Liturgii. Ze źródeł historycznych wiadomo, że szpitale budowano nie tylko w wielkich miastach, jak Konstantynopol, Antiochia czy Aleksandria, ale również w miastach na prowincji, np. w Salonice, Nicei, Kastorii, Efezie czy Koryncie. Zachowały się imiona nie tylko biskupów, ale również i mnichów oraz kapłanów, którzy szczególnie zaangażowani byli w organizację opieki zdrowotnej dla terminalnie chorych. W VI w. w Konstantynopolu aktywnością tego rodzaju zajmowali się Marathonius i Sampson ${ }^{26}$.

Od V w. coraz bardziej popularne stawało się pojmowanie Kościoła jako „duchowego szpitala”, w którym Lekarzem jest sam Chrystus. Miało ono podstawę w samej Dobrej Nowinie, z której można było wnioskować, że Chrystus jest dla ludzi nie tylko Zbawicielem, ale również i Lekarzem (por. Mt 9, 12). Już w Liście do Efezjan autorstwa św. Ignacego Antiocheńskiego Chrystus jest ukazany jako lekarz:

„Jeden tylko jest lekarz, cielesny i zarazem duchowy, zrodzony i nienarodzony, przychodzący w ciele Bóg, w śmierci życie prawdziwe, zrodzony z Maryi i zrodzony z Boga, najpierw podległy cierpieniu, a teraz już mu nie podlegający, Jezus Chrystus, nasz Pan"27.

Również św. Augustyn z Hippony nauczał, iż Chrystus jest Lekarzem $(\mathrm{Me}$ dicus) $)^{28} \mathrm{i}$ „Lekarstwem” (medicamentum) $)^{29}$ czy też „Lekarstwem pochodzącym z nieba" (medicina de coelo veniens) $)^{30}$. Jezus Chrystus jest źródłem pełni zdrowia, z której może czerpać człowiek poprzez przyjmowane z wiarą sakramenty. Choć uzdrowienie człowieka rozpoczyna się w ziemskim życiu, to pełnia uzdrowienia, odnosząca się zarówno do jego duszy, jak i ciała, przynależy do czasów ostatecznych, a więc po zmartwychwstaniu ciała, na końcu czasów ${ }^{31}$.

${ }^{26}$ Por. D.J. Constantelos, Byzantine Philanthropy - Part I, http://pemptousia.com/2016/08/byzantine-philanthropy-part-i/ [dostęp: 25.08.2016].

${ }^{27}$ Ignatius Antiochenus, Epistula ad Ephesios 7, 2, ed. P.Th. Camelot, SCh 10, Paris 1958, 7476, thum. A. Świderkówna: Ignacy z Antiochii, Do Kościoła w Efezie, w: Ojcowie apostolscy, PSP 45, Warszawa 1990, 68-69.

${ }^{28}$ Por. H. Schipperges, Zum Tradition des „, Christus medicus” im frühen Christentum und der älteren Heilkunde, „Arzt und Christ” 11 (1965) 12-22; G. Fichtner, Christus Medicus. Die Bezeichnung Christi als Arzt bei den lateinischen Kirchenvätern, Heildenberg 1965, passim.

${ }^{29}$ Por. Augustinus, In Epistulam Joannis ad Parthos tractatus decem 8, 14.

${ }^{30}$ Por. tenże, In Evangelium Joannis tractatus centum viginti quatuor 7, 2. Zob. P. Szczur, Chrystus: Bóg - Człowiek. Tytuły chrystologiczne w „Enarrationes in Psalmos” św. Augustyna (Psalmy I-CL), w: Tysiac imion Chrystusa. Seminarium Patrystyczne KUL 1983-1993, red. F. Drączkowski - J. Pałucki, Lublin 1994, 94, 100 i 109-110.

${ }^{31}$ Por. G.M. Baran, Chrystus Lekarzem i Lekarstwem z nieba w świetle Homilii św. Augustyna do Ewangelii i Pierwszego Listu Jana Apostoła, VoxP 30 (2010) t. 55, 43-62; zob. też A. Eckmann, Troska o ubogich w nauczaniu i działalności świętego Augustyna, VoxP 16 (1996) t. 30-31, 161-182. 
W komentarzu do przywołanej już przypowieści o Dobrym Samarytaninie św. Jan Chryzostom wyjaśnia duchowe źródła choroby oraz opisuje, w jaki sposób może dokonać się uzdrowienie. Człowiek zwiedziony przez demona dokonuje złego wyboru, wybiera własną drogę, po której idzie i na tej drodze ostatecznie napadają go zbójcy. Zostaje poraniony przez złe duchy i na wpół żywy porzucony. Chrystus znajduje oszukanego i poranionego człowieka, podnosi go mocą Ducha Świętego i namaszcza świętymi sakramentami, a następnie przenosi do gospody, czyli Kościoła, aby w pełni odzyskał zdrowie poprzez opiekę właściciela gospody, czyli kapłana ${ }^{32}$. Św. Jan Chryzostom, biskup Konstantynopola w latach 398-404, nie tylko nauczał o tym, że Kościół jest „duchowym szpitalem”, ale sam stworzył instytucję, którą nazwał voбоко $\mu \hat{i}$ ov, czyli miejscem do opieki nad chorymi. Powołanym do istnienia przez niego szpitalem kierowali kapłani, a zatrudnieni w nim byli lekarze, pomocnicy (írovproí) i kucharze ${ }^{33}$.

Należy pamiętać, iż rozwój chrześcijaństwa, zwłaszcza w Cesarstwie Bizantyńskim, nierozerwalnie związany był $\mathrm{z}$ tworzeniem instytucjonalnych form opieki nad umierającymi, jak to było w przypadku trędowatych, oraz z rozwojem holistycznego leczenia człowieka, w ramach którego troszczono się o ducha i ciało ${ }^{34}$. Chrześcijanie nie tylko dzielili się z potrzebującymi swymi dobrami, ale opiekowali się chorymi, bezdomnymi czy porzuconymi dzieć-

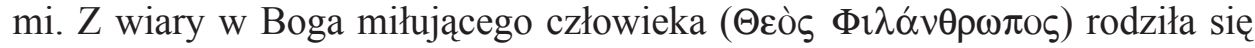
w nich głęboka wrażliwość na innych. Troska o cierpiących, obecna od samego początku chrześcijaństwa, po okresie prześladowań, zaczęła przybierać coraz to bardziej instytucjonalne formy. Chrześcijanie zaradzając potrzebom ludzi biednych i chorych praktycznie urzeczywistniali przykazanie miłości poprzez

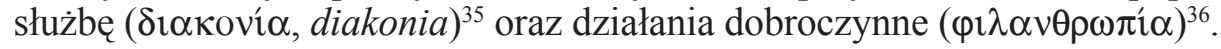

$\mathrm{Na}$ wzór szpitali i innych instytucji dobroczynnych funkcjonujących w Cesarstwie Bizantyńskim, od końca IV w. zaczęły powstawać podobne instytucje w Rzymie, a następnie w innych miastach Italii, a także w Galii, Hiszpanii i Afryce Północnej ${ }^{37}$. W tradycji chrześcijaństwa zachodniego wielki wkład w opiekę nad chorymi wniósł św. Benedykt z Nursji. W 529 r. założył on

${ }^{32}$ Por. Johannes Chrysostomus (?), In parabolam Samaritani, PG 62, 755-758.

${ }^{33}$ Por. Miller, The Birth of the Hospital in the Byzantine Empire, s. 55.

${ }^{34}$ Por. S. Stoddard, The Hospice Movement. A Better Way of Caring for the Dying, Brirarcliff Manor 1978, 100; Holistic Healing in Byzantium, ed. J.T. Chirban, Brookline (MA) 2010, passim.

${ }^{35}$ Por. D. Caner, Charitable Ministrations (Diakoniai), Monasticism, and the Social Aesthetic of Sixth-Century Byzantium, w: Charity and Giving in Monotheistic Religions, ed. M. Frenkel - Y. Lev, Berlin - New York 2009, 45-73.

${ }^{36}$ Por. D.J. Constantelos, Origins of Christian Orthodox Diakonia: Christian Orthodox Philanthropy in Church History, GOTR 52 (2007) 1-36; M. Wójcik, Świeccy fundatorzy instytucji dobroczynnych w Kościele starożytnym, VoxP 22 (2002) t. 42-43, 327-337.

${ }^{37}$ Por. A. Żurek, Działalność charytatywna Kościoła w Galii V-VI wieku, VoxP 16 (1996) t. 3031, 189-196; I. Milewski, Rozwój chrześcijańskich instytucji dobroczynnych w zachodniej części Cesarstwa Rzymskiego w IV i V wieku, PrzRel 40 (1996) nr 4 (182) 3-15. 
klasztor na Monte Cassino w Italii. Był to nie tylko ważny ośrodek dla rozwoju nauki i kultury, ale również istotne miejsce dla działalności medycznej i opiekuńczej. Reguła benedyktyńska nakazywała opiekę nad chorymi, co przede wszystkim odnosiło się do chorych braci, ale też do nich się nie ograniczała:

„O chorych należy troszczyć się przede wszystkim i ponad wszystko i służyć im rzeczywiście tak, jak Chrystusowi, bo On sam powiedział: «Byłem chory, a odwiedziliście Mnie» (Mt 25,36) oraz: «Co uczyniliście jednemu z tych braci moich najmniejszych, Mnieście uczynili» (Mt 25, 40)"38.

Erygowanie oraz uposażenie szpitali przez biskupów i opatów narzucało postanowienie synodu w Akwizgranie (817) ${ }^{39}$. Szpitale i przytułki zakładały również inne zakony, jak np. cystersi, augustianie, joannici, duchacze ${ }^{40}$. W Średniowieczu przy klasztorach na Zachodzie Europy powstawały szpitale i przytułki, w których leczono z chorób cielesnych i chorób duchowych ${ }^{41}$. Porad medycznych zazwyczaj udzielali zakonnicy, a leki pochodziły z klasztornych aptek. Tak, jak i w chrześcijaństwie wschodnim, zarówno opieka medyczna, jak i lekarstwa były bezpłatne ${ }^{42}$.

Z przedstawionych faktów jednoznacznie wynika, że posługa hospicyjna to dzieło, które ma korzenie chrześcijańskie, sięgające 2. poł. IV wieku. Wówczas to na terenie Cesarstwa Bizantyńskiego pojawiły się szpitale i ośrodki dla ludzi terminalnie chorych. Pierwsze hospicja powstały w celu ulżenia w cierpieniu ludziom chorym na trąd. Tego rodzaju opieka paliatywna nad ludźmi nieuleczalnie chorymi, a także nad będącymi w stanie terminalnym, była rewolucyjną nowością w świecie starożytnym. W czasach przedchrześcijańskich lekarze nie zajmowali się ludźmi śmiertelnie chorymi, gdyż wtedy powszechne było przekonanie, że jest to niezgodne z prawami natury i wolą bogów.

Chrześcijanie - wierząc w Boga, który jest Miłością i Który dla zbawienia człowieka stał się człowiekiem, umarł za grzechy świata i zmartwychwstał - objawiali tę Miłość Bożą, nie tylko we wspólnocie wierzących, ale wobec wszystkich potrzebujących pomocy. Opieka nad trędowatymi to pierwszy

${ }^{38}$ Benedicti Regula 36, ed. i tłum. A. Świderkówna: Święty Benedykt z Nursji, Reguła, w: Święty Benedykt z Nursji, Reguła. Święty Grzegorz Wielki, Dialogi. Księga druga, Tyniec - Kraków 1994, 152-155; więcej na temat działalności charytatywnej w Regule św. Benedykta i inych starożytnych regułach mniszych zob. B. Degórski, Uczynki miłosierdzia w świetle starożytnych regut mniszych, VoxP 16 (1996) t. 30-31, 259-274.

${ }^{39}$ Por. L. Szot, Powstanie i rozwój ruchu hospicyjnego, SW 46 (2009) 225.

${ }^{40}$ Por. J. Fijałek, Spoleczne tradycje organizacyjne i naukowe w opiece zdrowotnej do końca XVIII wieku, w: Historia medycyny, s. 213.

${ }^{41}$ Por. W. Szumowski, Historia medycyny, Warszawa 1961, 114.

${ }^{42}$ Por. J.S. Pelczar, Zarys dziejów miłosierdzia chrześcijańskiego w Kościele katolickim, Kraków 1916, 54. 
znany w historii świata przykład instytucjonalnej posługi hospicyjnej, w ramach której podmiotem troski był cały człowiek. Miłość okazywana trędowatym jest ponadczasowym przykładem, czym w swej istocie jest miłość chrześcijańska.

\section{THE GENESIS OF CHRISTIAN HOSPICE CARE}

\section{(Summary)}

Hospice care to terminally ill people was originated due to a sensitivity to the personal dignity of man. Christianity brought a special contribution to the care of terminally ill people in the history of the world. Institutionalized Christian hospice care was started in the second half of the fourth century. The first hospices were founded in the Byzantine Empire and were destined for people suffering from leprosy. In the article there are stated the facts relating to the biblical foundations of the theology of diakonia and examples of the involvement of the hierarchy in the creation of hospitals according to the principles of Christian ethics. The Author underlines that the first Christian hospices have been an integral part of monasteries.

Key words: History of Medicine, the Genesis of Hospice Care, Christianity, the Byzantine Empire, Leprosy, theology of diakonia.

Słowa kluczowe: historia medycyny, geneza opieki hospicyjnej, chrześcijaństwo, Cesarstwo Bizantyńskie, trąd, teologia diakonii.

\section{BIBLIOGRAFIA}

\section{Źródła}

Augustinus, In Epistulam Joannis ad Parthos tractatus decem, PL 35, 1977-2062.

Augustinus, In Evangelium Joannis tractatus centum viginti quatuor, PL 35, 1379-1976.

Benedicti Regula 36, ed. i thum. A. Świderkówna: Święty Benedykt z Nursji, Reguła, w: Święty Benedykt z Nursji, Reguła. Święty Grzegorz Wielki, Dialogi. Księga druga, Tyniec - Kraków 1994, 24-263.

Gregorius Nazianzenus, Oratio 43, PG 36, 493-605.

Gregorius Nyssenus, De pauperibus amandis orationes duo, ed. A. van Hecks, Leiden 1964.

Ignatius Antiochenus, Epistula ad Ephesios, ed. P.Th. Camelot, SCh 10, Paris 1958, 66-

92, tłum. A. Świderkówna: Ignacy z Antiochii, Do Kościoła w Efezie, w: Ojcowie apostolscy, PSP 45, Warszawa 1990, 66-73.

Johannes Chrysostomus (?), In parabolam Samaritani, PG 62, 755-758.

\section{Opracowania}

Avalos H., Health Care and Rise of Christianity, Grand Rapids (MI) 1999.

Baran G.M., Chrystus Lekarzem i Lekarstwem z nieba w świetle Homilii św. Augustyna do Ewangelii i Pierwszego Listu Jana Apostoła, VoxP 30 (2010) t. 55, 43-62. 
CAner D., Charitable Ministrations (Diakoniai), Monasticism, and the Social Aesthetic of Sixth-Century Byzantium, w: Charity and Giving in Monotheistic Religions, ed. M. Frenkel - Y. Lev, Berlin - New York 2009.

Constantelos D.J., Byzantine Philanthropy - Part I, http://pemptousia.com/2016/08/ byzantine-philanthropy-part-i/_[dostęp: 25.08.2016].

Constantelos D.J., Origins of Christian Orthodox Diakonia: Christian Orthodox Philanthropy in Church History, GOTR 52 (2007) 1-36.

CRISLIP A.T., From Monastery to Hospital: Christian Monasticism and the Transformation of Health Care in Late Antiquity, Ann Arbor (MI) 2005.

DEGÓRSKi B., Uczynki miłosierdzia w świetle starożytnych regut mniszych, VoxP 16 (1996) t. 30-31, 259-274.

EcKmann A., Troska o ubogich w nauczaniu i działalności świętego Augustyna, VoxP 16 (1996) t. 30-31, 161-182.

Ferngren G.B., Medicine and Health Care in Early Christianity, Baltimore (Md) 2009.

Fichtner G., Christus Medicus. Die Bezeichnung Christi als Arzt bei den lateinischen Kirchenvätern, Heildenberg 1965.

FiJalek J., Rozwój szpitalnictwa, w: Historia medycyny, red. T. Brzeziński, Warszawa 1995, 398-399.

FiJAlek J., Społeczne tradycje organizacyjne $i$ naukowe $w$ opiece zdrowotnej do końca XVIII wieku, w: Historia medycyny, red. T. Brzeziński, Warszawa 1995, 211-227.

Flemming H., Post-Hippocratic Medicine: The Problem and the Solution. How the Christian Ethic has Influenced Health Care, Taunton 2010.

Foucault M., The Birth of the Clinic: An Archeology of Medical Perception, transl. A.M.S. Smith, New York 1973.

Holistic Healing in Byzantium, ed. J.T. Chirban, Brookline (MA) 2010.

Horden P., The Christian Hospital in Late Antiquity: Break or Bridge?, w: GesundheitKrankheit. Kulturtransfer medizinischen Wissens von der Späntantike bis in die Frühe Neuzeit, ed. F. Steger - K.P. Jankrift, Cologne 2004, 88-92.

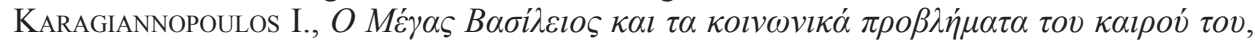
„Byzantina” 11 (1982) 113-132.

LoNGOSz S., Ksenodochium - hospicjum wczesnochrześcijańskie, VoxP 16 (1996) t. 30-31, 275-336.

Malina B. - Rohrbaugh R.L., Social Commentary on the Synoptic Gospels, Minneapolis (Minn.) 1992.

Milewski I., Rozwój chrześcijańskich instytucji dobroczynnych w zachodniej części Cesarstwa Rzymskiego w IV i V wieku, PrzRel 40 (1996) nr 4, 3-15.

Miller T.S. - Nesbitt J., Saint John Chrysostom and the „Holy Disease”: an excerpt from an unpublished, anonymous eulogy (BHG 871; CPG 6517), „Rivista di studi bizantini e neoellenici" 42 (2006) 33-34.

Miller T.S. - Nesbitt J.W., Walking Corpses. Leprosy in Byzantium and the Medieval West, Ithaca - London 2014.

Miller T.S., The Birth of the Hospital in the Byzantine Empire, Baltimore (Md) 1985.

Naumowicz J., Instytucje charytatywne św. Bazylego. „Bazyliada”, VoxP 16 (1996) t. 3031, 125-139.

Ordon H., Pawłowa argumentacja na rzecz niesienia pomocy potrzebujacym, VoxP 16 (1996) t. 30-31, 75-83.

Pelczar J.S., Zarys dziejów miłosierdzia chrześcijańskiego w Kościele katolickim, Kraków 1916. 
Porter D., Health, Civilization and the State. A History of Public Health from Ancient to Modern Times, London - New York (NY) 1999.

ReIch K.A., Figuring Jesus. The Power of Rhetorical Figures of Speech in the Gospel of Luke, Leiden - Boston (Mass.) 2011.

Riddle D.W., Early Christian Hospitality: A Factor in the Gospel Transmission, JBL 57 (1938) $\mathrm{nr} 2,141-154$.

Ringe S.H., Luke, Luisville (Ky) 1995.

Risse G.B., Mending Bodies, Saving Souls: A History of Hospitals, New York 1999.

Rosen G., A History of Public Health, Baltimore - London 1958.

Schipperges H., Zum Tradition des „Christus medicus” im frühen Christentum und der älteren Heilkunde, „Arzt und Christ” 11 (1965) 12-22.

SidÉRIs G., Lèpre et lépreux à Constantinople. Maladie, épidémie et idéologie imperial à Byzance, w: La Paléodémograpie. Mémoire d'os, memoire d'hommes. Actes des $8^{e}$ journées antropologiques de Valbonne 5 au 7 Juin 2003, ed. L. Buchet - C. Dauphin - I. Séguy, Antibes 2006, 187-207.

Sigerist H.E., Civilization and Disease, Ann Arbor (MI) 1915.

Stoddard S., The Hospice Movement. A Better Way of Caring for the Dying, Brirarcliff Manor 1978.

Szczur P., Chrystus: Bóg - Człowiek. Tytuły chrystologiczne $w$ „Enarrationes in Psalmos" św. Augustyna (Psalmy I-CL), w: Tysiac imion Chrystusa. Seminarium Patrystyczne KUL 1983-1993, red. F. Drączkowski - J. Pałucki, Lublin 1994, 93-115.

Szczur P., Rabula, EK XVI 1023-1024.

Szot L., Powstanie i rozwój ruchu hospicyjnego, SW 46 (2009) 221-236.

Szumowski W., Historia medycyny, Warszawa 1961.

Vööвus A., History of Asceticism in the Syrian Orient. A Contribution to the History of Culture in the Near East, I: The Origin of Asceticism. Early Monasticism in Persia, Leuven 1958.

Wóscik M., Świeccy fundatorzy instytucji dobroczynnych $w$ Kościele starożytnym, VoxP 22 (2002) t. 42-43, 327-337.

Żurek A., Działalność charytatywna Kościoła w Galii V-VI wieku, VoxP 16 (1996) t. 3031, 189-196. 
